\title{
UM ESPAÇO PARA COMPREENDER O SAGRADO: A ESCOLARIZAÇÃO DO ENSINO RELIGIOSO NO BRASIL
}

\author{
A space to understand the sacred: the school education \\ process of the religious teaching in Brazil
}

\author{
Sylvio Fausto Gil Filho* \\ Sérgio Rogério Azevedo Junqueira**
}

\begin{abstract}
RESUMO
O objetivo deste artigo é discutir na perspectiva histórica a crise epistemológica do Ensino Religioso ainda inconcluso no ambiente educacional do Brasil. Mesmo reconhecendo o pluralismo religioso no Brasil, é notável a disputa do espaço escolar pelas tradições religiosas, inferindo na alteração do foco de estudo deste componente curricular. Esta reflexão, articulada a partir do processo de escolarização do Ensino Religioso, demonstra o debate recente e o redimensionamento do objeto desta disciplina. Apresenta a discussão do pensamento e a análise do discurso religioso neste processo, pois a escola é um espaço privilegiado para a compreensão do sagrado em nossa sociedade.
\end{abstract}

Palavras-chave: sagrado; educação; ensino religioso; escola.

\begin{abstract}
The objective of this article is to discuss in the historical perspective the epistemological crisis of the Religious Teaching unconcluded in the educational atmosphere of Brazil. Although recognizing the religious pluralism in Brazil is notable the dispute of the school space by the

* Professor Adjunto Doutor do Departamento de Geografia e do Programa de Pós-Graduação Mestrado e Doutorado em Geografia da Universidade Federal do Paraná. Membro do Núcleo Paranaense

** Professor do Programa de Mestrado em Educação da PUCPR; Consultor da Secretaria Estadual de Educação do Paraná; Secretário do Fórum Nacional Permanente do Ensino Religioso (FONAPER); Líder do Grupo de Pesquisa Educação e Religião (GPER); Membro do Núcleo Paranaense de Pesquisa em
\end{abstract} de Pesquisa em Religião (NUPPER). Religião (NUPPER). 
religious traditions, inferring in the alteration of the study focus of this curricular component. This reflection articulated starting from the school education process of the Religious Teaching demonstrates the recent debates and the new dimension of the object of this disciplines. It presents the discussion of the thought and the analysis of the religious discourse in this process, because the school is a privileged space for the understanding of the sacred in our society.

Key-words: sacred; education; religious teaching; school.

\section{Introdução}

A discussão acerca do religioso ocorre no cotidiano da sociedade, onde nem sempre é possível uma reflexão mais aprofundada. Apenas se percebe a veiculação de colocações do senso comum sem permitir uma maior compreensão das manifestações religiosas que inundam o dia a dia das comunidades. No currículo escolar identifica-se um espaço formal para esta discussão denominado Ensino Religioso. Este componente curricular está presente no ambiente escolar brasileiro desde o século XVIII, inicialmente na perspectiva da instituição religiosa, mas progressivamente vem assumindo o rosto da escola com uma leitura e interação pedagógica integradas no conjunto dos processos educativos que a constituem. A história do Ensino Religioso auxilia na reflexão sobre o objeto de estudo desta disciplina, assim como na identificação de espaços/lugares para compreender o sagrado que se percebem circunscritos ao cotidiano escolar.

\section{Escolarização do Ensino Religioso}

O processo de escolarização do Ensino Religioso no Brasil inicialmente ocorreu na transposição do trabalho religioso realizado nas paróquias para o espaço escolar. O modelo caracterizava-se antes de tudo por um código doutrinal (dogma, moral, sacramentos), de verdade sobrenatural diretamente revelada de Deus. O professor, com autoridade dada pela Igreja, 
utilizava um catecismo de linguagem neo-escolástica. A catequese era concebida, sobretudo, como uma introdução sistemática e orgânica desse complexo doutrinal do catecismo, onde sua finalidade primeira era o conhecimento exato e intelectual das verdades de fé. Essa atividade de catequese se desenvolvia a partir do aprender de memória e no recitar as perguntas e respostas do catecismo oficial. O caráter intelectual ou cognitivo desta catequese era absolutamente dominante, a formulação exata e integral deste código doutrinal era reservada ao magistério da Igreja e vinha aprofundada pela teologia.

Ao longo dos períodos do Colonialismo e do Império brasileiro (séculos XV a XIX), é efetivado o Ensino Religioso como cristianização por delegação pontifícia, justificando o poder estabelecido. A educação foi implantada e ministrada sob os domínios dos Jesuítas. O governo não intervinha diretamente como primeiro interessado, nem propunha uma filosofia educacional, pois competia aos religiosos, controlados pelo governo, organizar e fazer funcionar o processo de escolaridade e catequização. A grande característica desta fase é uma educação humanista, que se evidencia por ser individualista, centrada nos valores propostos pelo Renascimento, e favorecer a ideologia reinante, empregando métodos tradicionais. O ensino da religião é questão de cumprimento dos acordos estabelecidos entre a Igreja Católica e o Monarca de Portugal. As leis, decretos e instruções em geral põem em primeiro plano a evangelização dos gentios. O caráter disciplinador de toda catequese concorre para a transmissão de uma cultura que visa à adesão ao catolicismo.

Em meados do século XVIII (1759), com a expulsão dos jesuítas, a educação passa por transformações, pois o Estado assume o que existe de Educação nesta fase. A reforma Pombalina implanta um modelo impregnado pelo racionalismo do Iluminismo e a educação permanece de caráter elitista. O ensino da religião nesta fase passa pelo crivo da Inquisição. Caracteriza-se como catequese dirigida aos índios, escravos e ao povo como um todo. A elite brasileira é educada nas escolas da Coroa (Portugal) e o que se faz na realidade é a memorização de fórmulas e a prática de uma vivência cristã.

Esta orientação foi proposta no Sínodo de 1707, na Bahia, que posteriormente foi assumida pelo episcopado nacional desta fase, através das “Constituições do Arcebispado da Bahia”, que manifesta logo no pri- 
meiro capítulo grande cuidado pela formação religiosa e cristã da população, inclusive dos escravos.

O Ensino Religioso nas escolas vigorou desde o Sínodo Diocesano do Brasil de 1701 e durante todo o Império, que vedava aos leigos a ousadia de ser instrutores de religião, com penas pesadas como punição financeira e excomunhão. Esta ação é na realidade uma espécie de adaptação das Constituições do Arcebispado à Independência do país e à abolição da Inquisição.

Progressivamente, o Estado, então ainda monárquico, amplia o pequeno sistema educacional, com a criação de cursos do ensino superior (Medicina e Cirurgia). Esses cursos são criados, bem como a Academia de Belas Artes. Não há, porém, significativa evolução no ensino para as classes populares, enquanto que, para as classes mais abastadas, criam-se: bibliotecas, imprensa, teatro, escolas especializadas. O Ensino Religioso é de caráter mais privativo e doméstico do que institucional, por meio das Confrarias Religiosas que ajudam a eliminar a distância existente entre a cultura européia e a cultura africana, processando-se a efetivação do sincretismo religioso.

O projeto religioso da educação não conflita com o projeto político dos reis e da aristocracia; é a fase da educação sob o motivo religioso. O que se desenvolve é a evangelização, segundo os esquemas da época, ou seja, a cristianização por delegação pontifícia, autoridade de Roma, como justificativa do poder estabelecido, em decorrência do regime de padroado.

Dessa forma, o que se desenvolve como Ensino Religioso é o Ensino da Religião, como evangelização dos gentios e Catequese dos negros, conforme os acordos estabelecidos entre o Sumo Pontífice e o Monarca de Portugal. Como manifestação de um esforço de escolarização da religião, encontramos a Lei de 15 de outubro de 1827, que era para regulamentar o inciso 32 do art. 179 da Constituição Imperial, ou seja, a lei complementar, no seu artigo $5^{\circ}$.

Mas, ao longo do Império, nasce a idéia do respeito à diversidade da população. Em um projeto de Lei da Constituição, Rui Barbosa propunha em seu artigo $1^{\circ}$, terceiro parágrafo, que nas escolas mantidas pelo Estado não deveria ser imposta uma crença.

Com a proclamação da República dos Estados Unidos do Brasil, em 15 de novembro de 1889, ocorre que as tendências secularizantes exis- 
tentes no Império foram de fato assumidas pelo novo regime, organizado a partir do ideário positivista, que, no campo da educação, é responsável pela defesa da escola leiga, gratuita, pública e obrigatória, rejeitando, portanto, a ideologia católica, que exercia o monopólio do ensino de caráter elitista. Sob a influência de Comte, Benjamin Constant empreendeu a reforma de 1890, quando ministro da Instrução, Correios e Telégrafos.

Outra reforma, a de 1911, também representa o ideal positivista, sobretudo no que se refere à introdução das disciplinas científicas, superando o caráter marcadamente humanístico de nossa tradição cultural. No entanto, estas duas reformas não conseguem impor tal tendência.

Assistimos, desde a primeira república, ao confronto entre a Igreja e o Estado. Na Constituição de 1891, o artigo 72, parágrafo 6, traz a seguinte disposição: “(...) será leigo o ensino ministrado nos estabelecimentos públicos”, causando grandes divergências, tanto que nos anos seguintes o Episcopado toma posição de defesa em relação ao ensino da religião como colorário da liberdade religiosa, da liberdade de consciência.

A Constituição de 1934, no artigo 153, admite o Ensino Religioso, mas de caráter facultativo, ministrado de acordo com os princípios da confissão religiosa do aluno, sendo manifestada pelos pais e/ou responsáveis, constituindo matéria do currículo nas escolas públicas. Surgem grandes debates, retornando à questão da liberdade religiosa, à pressão da Igreja e tantos outros interesses. É uma fase em que se buscam modelos de educação que exaltam a nacionalidade, a valorização do ensino profissional. Tanto que as Constituições de 1937, 1946 e de 1967 do Brasil mantêm a questão do Ensino Religioso como matéria do currículo, mas de freqüência livre para o aluno, sempre considerando o credo da família.

Por volta de 1965, já se vislumbrava uma crise, da qual se tomava conhecimento aos poucos e que podia ser expressa assim: o Ensino Religioso perdeu sua função catequética, pois a escola descobre-se como instituição autônoma que se rege por seus próprios princípios e objetivos, na área da cultura, do saber e da educação. A manifestação do pluralismo religioso é explicitada de forma significativa; não é mais compatível compreender uma área curricular que doutrine e que não conduza a uma visão ampla e integral do ser humano.

Diante deste novo momento, o catecismo deixa a escola, que busca uma nova identidade para o Ensino Religioso, como elemento integrante do processo educativo. A definição desta nova identidade exigiu também 
anos de prática e estudo; contribuíram para isso os Encontros de Ensino Religioso (ENER), desde 1974.

Esta busca de identidade e redefinição do papel do Ensino Religioso na escola, conjugada com a discussão de sua manutenção em termos de legislação, foi de significativa importância no processo da revisão constitucional nos anos 80.

Quando da Constituinte que culminou com a promulgação da Constituição de 1988, foi organizado um movimento nacional para garantir o Ensino Religioso. A emenda constitucional para o Ensino Religioso foi a segunda maior emenda popular que deu entrada na Assembléia Constitucional, pois obteve 78.000 assinaturas.

O passo posterior foi a elaboração de uma nova concepção do Ensino Religioso, que fosse diferente da perspectiva da catequese. Uma busca desta proposta podemos encontrar em elementos do substitutivo para a emenda da LDBEN 9394/96, que considera que a educação hoje, caracterizada por um pluralismo de idéias pedagógicas, é fator essencial que garante ao Estado democrático de direito a construção de uma sociedade justa, livre e democrática. Ela revela e, ao mesmo tempo, sustenta e propaga uma filosofia de vida, uma concepção de ser humano e da sociedade, indicando que a educação propõe um processo de humanização, personalização e aquisição de meios para a atuação transformadora da sociedade.

Foram apresentadas três proposições de mudanças para o artigo 33 da LDBEN 9394/96 sobre o Ensino Religioso. O primeiro Projeto de Lei, de $n^{0}$ 2.757/97, não introduziu grandes alterações: propôs simplesmente a retirada da expressão “sem ônus para os cofres públicos”. A justificativa está baseada no princípio de que o Ensino Religioso é componente curricular da Educação Básica e de importância para a formação do cidadão e para seu pleno desenvolvimento como pessoa. Por conseqüência, é parte do dever constitucional do Estado em matéria educativa.

O segundo projeto, o de ${ }^{\circ} 2.997 / 97$, de autoria do deputado Maurício Requião (PMDB-PR), propôs alterações significativas na redação do artigo 33 da LDB, indicando que o Ensino Religioso fosse parte integrante da formação básica do cidadão, sendo que vedava qualquer forma de doutrinação ou proselitismo. Dizia que os conteúdos deveriam respeitar a diversidade cultural brasileira e deveriam ser definidos segundo parâmetros curriculares nacionais, de comum acordo com as diversas denominações religiosas ou entidades que as representam. 
O Projeto de Lei no 3.043/97 foi apresentado na Câmara dos Deputados em regime de urgência constitucional e propôs a nova redação do Art. 33 da LDBEN 9394/96, na qual: “o caráter ecumênico, de acesso a conhecimentos que promovam a educação do senso religioso respeitado as diferentes culturas e confessional e interconfessional”'

Os três projetos evidenciam importantes convergências e adotam o princípio de que o Ensino Religioso é parte integrante essencial da formação do ser humano, como pessoa e cidadão, estando o Estado obrigado a promovê-lo, não só pela previsão de espaço e tempo na grade horária curricular da Educação Básica pública, mas também pelo seu custeio, quando não se revestir de caráter doutrinário ou proselitista, possibilitando aos educandos o acesso à compreensão do fenômeno religioso e ao conhecimento de suas manifestações nas diferentes denominações religiosas.

Desse movimento nasce o terceiro momento, não mais uma simples preocupação só com o conteúdo, ou com o método, ou mesmo somente com o sujeito, mas todos esses elementos devem ser considerados conjuntamente. Entretanto, com um paradigma que identifica toda a escola, ou seja, conteúdo, métodos e atenção ao sujeito deve ser a operacionalização de uma opção: a escolarização dessa disciplina, da presença eclesial. Não é o caso continuar com uma identidade paroquial na escola, mas confrontar corajosamente a identidade desse espaço, que possui uma função social e eclesial.

O Ensino Religioso sofreu um lento processo de alteração em conseqüência do desenvolvimento do país, de sua autocompreensão e, portanto, das opções políticas.

Na realidade esta alteração da legislação foi conseqüência de um significativo movimento articulador promovido pelo Fórum Nacional Permanente do Ensino Religioso - FONAPER, instalado no dia 26 de setembro de 1995, em Florianópolis (SC), por ocasião da celebração dos 25 anos da Assembléia Ordinária do Conselho de Igrejas para a Educação Religiosa - CIER, como um espaço pedagógico centrado no atendimento ao direito do educando de ter garantido a educação de sua busca do Transcendente/ Imanente e ainda espaço aberto para refletir e propor encaminhamentos pertinentes ao Ensino Religioso, sem discriminação de qualquer natureza.

1 Na tentativa de atender a todos, a lei foi registrada desta forma, mantendo vários conceitos contraditórios. 
A história do Ensino Religioso na educação brasileira foi sempre um processo político de disputa entre tradições religiosas e o Estado; entretanto, o questionamento ao longo dos anos foi sempre o mesmo: por que preparar os fiéis dentro do espaço escolar? Porém, caso este componente colocado no currículo seja justificado pedagogicamente, qual seria de fato o papel do Ensino Religioso na formação integral das novas gerações?

O processo de alteração de um projeto político-religioso, em que a escola foi considerada um espaço de atuação das igrejas para formar seus fiéis, para um projeto político outrora instituído, requer que se conceba a escola num lugar de compreensão e convivência da pluralidade nacional. Vivemos em um mundo diversificado de idéias onde a opção religiosa se manifesta como direito à liberdade de crenças, cada uma delas representando uma leitura de verdade, possibilitando que as pessoas se relacionem com "forças" ou "seres" sobrenaturais nos quais se acredita. No mundo atual, a liberdade é percebida como poder pleno e incondicional da vontade de determinar a si mesmo ou para ser autodeterminada.

É importante compreender que a religião também tem um papel importante na formação do indivíduo como cidadão, no respeito ao outro, na busca da dignidade, da igualdade e da justiça, direcionando o indivíduo para uma melhor forma de viver e nortear os princípios como solidariedade, amor ao próximo e a justiça, tendo a finalidade de garantir o respeito às normas, às regras e aos valores da moralidade estabelecida pela sociedade.

Hoje todos têm o direito de exercer a sua crença religiosa, de manifestar a sua opinião e expressão, sem interferência. Têm a liberdade de mudar de religião ou crença, de se manifestar pelo ensino, pela prática, pelo culto e pela observância, isolada ou coletivamente, em público ou em particular. Este direito está previsto na Declaração Universal dos Direitos Humanos: "Toda pessoa tem o direito à liberdade de pensamento, consciência e religião; este direito inclui a liberdade de mudar de religião ou crença e a liberdade de manifestar essa religião ou crença, pelo ensino, pela prática, pelo culto e pela observância, isolada ou coletivamente, em público ou em particular.” (Artigo XVIII da Declaração Universal dos Direitos Humanos).

As Diretrizes Curriculares do Ensino Religioso apontam para que a disciplina seja trabalhada na escola de forma a permitir que tanto o professor quanto os alunos possam refletir sobre a diversidade religiosa. Diversidade 
essa presente na sociedade, e suas diferentes manifestações, no sentido da formação integral do educando, bem como a expansão do seu conhecimento.

Ao se tratar qualquer encaminhamento metodológico do Ensino Religioso, os princípios evidenciados nas Orientações Curriculares do Ensino Religioso serão o “filtro”. Isso para que o conteúdo possa ser trabalhado na sala de aula, ou seja, o professor pode ampliar ou não o conteúdo proposto, mas não poderá se esquecer de que qualquer conteúdo necessita ser considerado à luz destes princípios. ${ }^{2}$

Nas instituições sociais, mais especificamente na escola, o educando experimenta e vivencia valores que o orientarão para a vida. Ele sistematiza o conhecimento científico e se capacita para a participação como cidadão, no trabalho, na política, na cultura, na religião e no lazer.

Cabe ao Estado, por incumbência da sociedade, preocupar-se com a educação de todas as dimensões do ser humano, garantindo o respeito ao pluralismo de idéias. Também é seu dever garantir as condições para educação da dimensão religiosa dos cidadãos, tendo a escola como lugar onde se cultivam na pessoa as razões transcendentais, por serem estas fontes de cultura e força propulsora para o ser humano assumir seu engajamento na história e fortalecer a ação cidadã.

\section{O debate recente do objeto do ensino religioso}

O debate sobre o objeto do Ensino Religioso tomou outros rumos no cenário nacional, produto do contexto da lei federal número 9394, de 1996, e da nova redação do artigo 33, lei número 9475, de 1997, que abriu a possibilidade de o Estado fazer uma mediação dos interesses das instituições religiosas no que tange à ação nas escolas, principalmente públicas. Se em um momento tal intervenção parecia forçada, em outro proporcionava novas oportunidades ao diálogo inter-religioso ainda incipiente no Brasil. A menção, na lei, da necessidade de uma entidade civil inter-religiosa, de

2 FÓRUM NACIONAL PERMANENTE DO ENSINO RELIGIOSO. Parâmetros Curriculares Nacionais - Ensino Religioso. São Paulo: Ave Maria, 1997. 
caráter consultivo para o Ensino Religioso, que fosse interlocutora junto aos agentes de educação do Estado, precipitou um processo de reestruturação das relações entre as instituições religiosas ainda inacabadas. Afinal, quais elementos dos diversos discursos das entidades ecumênicas e inter-religiosas, no fim do século XX, proporcionariam consensos sucessivos sobre o Ensino Religioso nas escolas públicas? Tal resposta não seria direta, pois o contexto que se apresentou colocou em questão o senso de propósito dessas entidades e abriu novas fissuras no discurso laicizante dos especialistas em educação participantes das estruturas do Estado. Na medida em os Conselhos de Educação dos Estados da Federação indicariam os parâmetros curriculares para a renascida disciplina, havia uma primeira tendência: um discurso acadêmico que priorizasse o saber quase técnico sobre o assunto. No mesmo contexto, o Ministério de Educação não forneceu um parecer nacional definitivo sobre área de formação nas Universidades e Faculdades. Havia diversos atores sociais empenhados nesta discussão primordial; reunia instituições religiosas, o Estado, clérigos, líderes religiosos, professores, pesquisadores e especialistas da religião e da educação. O Fórum Nacional Permanente do Ensino Religioso (FONAPER) se apresentava com um “agora” da ação desses atores sociais que oscilam entre o discurso acadêmico e o político.

No campo do discurso dos líderes religiosos, cada instituição religiosa indicava um prisma específico sobre a questão, que podemos categorizar em três classes de representações:

(i) As representações legitimadas: com destaque a Igreja Católica Romana, com a posição de quem tenta centralizar as ações na política do diálogo inter-religioso católico ${ }^{3}$ que reproduz a tendência já demonstrada no plano ecumênico, ou seja, a idéia de Igreja Mater e fideicomissária do Cristianismo. A representação hegemônica católica traduz-se como uma cultura religiosa dominante no Brasil.

(ii) As representações de resistência: onde os grupos minoritários buscam uma posição específica no debate com um discurso,

3 O discurso inter-religioso católico refere-se à legitimação do diálogo capitaneado pela Igreja Católica Romana no pontificado do Papa João Paulo II com as religiões fora do âmbito cristão. Mantém algumas características do discurso ecumênico católico quando a Igreja Católica Romana se coloca como a Igreja Mater responsável em chamar todos os cristãos para o diálogo. Apresenta, muitas vezes, características de restauração da unidade cristã, sendo a Igreja Católica Romana sua fideicomissária. 
por vezes, que não consegue ultrapassar os limites da confessionalidade. Igrejas Protestantes históricas, em muitas situações, apresentam representações com característica de escapar às hegemonias. As religiões afrobrasileiras articulam também representações de resistência. Os discursos das Religiões que apresentam comunidades de um grupo cultural específico imigrante podem ser considerados como de resistência. Como, por exemplo, o Judaísmo e o Islamismo no Brasil.

(iii) As representações projetadas: são aquelas articuladas por grupos religiosos que apresentam elementos novos ao debate por representarem mudanças no plano discursivo ou mudanças na prática cultural. Neste aspecto, algumas Igrejas Pentecostais e Neopentecostais, com sucesso no afã missionário, representam uma base cultural diferenciada. Constituem-se renovadas representações que questionam constantemente as representações hegemônicas. O Budismo e o Espiritismo Kardecista também representam perspectivas alternativas no plano discursivo. Tomam como base a idéia de reencarnação e as conseqüências desta base doutrinária na visão de mundo. Ainda podemos destacar o discurso dos bahá'ís, na medida em que constroem uma representação projetada, em um paradigma diferenciado, calcado na premissa da unidade da religião no que tange a sua Realidade Última. Nesta perspectiva, a verdade religiosa é considerada relativa; o que possibilita, no plano discursivo, a ultrapassagem dos limites enraizados do confessional.

A discussão sobre o objeto do Ensino Religioso neste contexto acabou por priorizar uma abordagem da antropologia religiosa, na medida em que as experiências religiosas diversas percebidas são as bases de construção de um questionamento existencial. O conceito chave é o fenômeno religioso como se apresenta no texto dos Parâmetros Curriculares Nacionais, construídos pelo FONAPER. O texto sugere que o fenômeno religioso é uma questão dada à consciência do homem diante da busca do Transcendente. Esta busca é impulsionada por um impulso a priori da experiência humana e justifica-se enquanto projeto irresoluto existencial do homem. Deste modo, a recuperação da questão primária do homem reabriria o processo de construção e reconstrução intelectual. Todavia, as respostas a este 
questionamento são dadas pela articulação do poder no plano do discurso. As instituições colocam-se em situação de autoridade, legitimada pelos seus interlocutores fornecerem respostas conclusivas. No plano do discurso racional, a Teologia e a Filosofia seriam os alicerces necessários à relativização. Todavia, na práxis, ainda sob o poder institucional religioso, a sua autonomia em muitas situações é limitada. Mas, o caráter existencial dado à interpretação do fenômeno religioso revela um conflito epistemológico de difícil solução no discurso pedagógico. Este conflito reside na ausência de um conceito fundador que permita, de modo universal, reunir a diversidade das hierofanias e a conexão das experiências individuais e coletivas do fenômeno religioso. ${ }^{4}$ Neste intuito, é necessária uma diferenciação do que seria religioso daquilo que não seria, entretanto, fora de um juízo de valor para definir melhor o campo de estudo com objetividade.

A aplicação de métodos fenomenológicos, por exemplo, como instrumentos interpretativos por si só não resolverá a questão da subjetividade fundadora ${ }^{5}$ que permeia o discurso religioso. Neste ponto, a busca das essências absolutas, em cada fenômeno, na forma como se apresentam à consciência, é avessa a uma teoria geral da realidade. De certo modo, a fenomenologia religiosa garante auspícios para pesquisa, mas deixa a desejar no plano das estruturas pedagógicas do conhecimento.

Nosso pressuposto é que existe um conflito irresoluto entre os discursos religiosos e o impacto de vários aspectos da chamada pósmodernidade. Esse conflito tende à implosão de paradigmas científicos totalizantes.

4 Muito embora, na sua origem grega, fenômeno signifique aparência sensível que se opõe à realidade, no sentido moderno, a partir do século XVIII, o termo passa a ser considerado com objeto do conhecimento humano de modo específico. Em Hobbes, fenômeno guarda o sentido de qualquer objeto submetido ao conhecimento humano e, em Kant, possui um caráter de relação sujeito-objeto que é uma representação. Mas, em Hursserl, o fenômeno é algo que se manifesta em si mesmo na sua essência, o que pressupõe um criticismo na análise a partir de um método. A interpretação que podemos inferir da proposição de objeto do Ensino Religioso dos Parâmetros Curriculares Nacionais, (FONAPER, 1997) é que ele indica o fenômeno religioso de como a religião é dada ao conhecimento humano, o que deixa em aberto a questão do método.

5 O discurso religioso preconiza uma continuidade através de um sujeito fundador ideal. Todavia, a ausência de uma subjetividade fundadora na análise (como em FOUCAULT, 1997), que permitiria avaliar a formação discursiva no plano da descontinuidade, nos apresenta como um problema insuperável para análise do discurso religioso. 


\section{Ensino religioso e o redimensionamento do objeto}

O pluralismo religioso, cada vez mais, se consolida como uma realidade social urbana, fruto da dinâmica cultural pós-moderna. A pósmodernidade representa, entre outras características, a implosão dos grandes paradigmas e a fragmentação do conhecimento. No plano das instituições religiosas, representa a relatividade dos discursos, no que tange às respostas ao um mundo em constante mutação. O que se apresenta como pós-modernidade, neste caso, se aproxima ao solapamento da "grande narrativa”6 apontado por Lyotard para uma série de versões possíveis. De certo modo, na pós-modernidade há uma reabilitação da narrativa mítica, pois, cada vez mais, o limite da modernidade não consegue criar metadiscurso e legitimá-los. O metadiscurso é um dispositivo de legitimação dos discursos de caráter totalizante, que entra em crise junto com a filosofia metafísica. Na historiografia, a metanarrativa passa a ser vista com desconfiança. Esta função se dispersa em vários núcleos de elementos discursivos que colocam em questão as nossas certezas. No plano do discurso religioso, este efeito é mais contundente, visto que as instituições religiosas utilizam-se do metadiscurso como legitimação de seu papel e de sua idéia de ordem social. Na pós-modernidade, o sistema se autolegitima na medida direta da produção e acessibilidade de informações e o poder de operacionalizá-las. Assim, o jogo do poder e legitimação do discurso se faz em outras regras, desconstruindo os metadiscursos e colocando-os em crise.

Deste modo, as condições pós-modernas não conseguem ir além dos fragmentos. Assim, estamos diante de um germe da multiplicidade sem fim, que anuvia as distinções do que é a mesma coisa e o diferente. O novo é definido somente na abstração, na medida em que as provas cabais do concreto são submetidas a uma variedade de discursos despregados de um paradigma totalizante legítimo.

Religião é um fenômeno complexo, multifacetado e de difícil definição. Baseado em Momen, ${ }^{7}$ podemos considerar três aspectos interdependentes:

6 LYOTARD, Jean-François. Réponse à la question: qu'est-ce que le postmoderne. Critique, Paris, n. 419, 1982.

7 MOMEN, Moojan. The phenomenon of religion - a thematic approach. Oxford: Oneworld, 1999. 
- $\quad$ No plano individual, é realizado a partir da experiência do sagrado;

- No plano conceitual e doutrinal, é a idéia universal de uma "Realidade Última” e a relação do homem com esta Realidade;

- No plano social, a religião está associada com a maior ou menor coesão social e integração do indivíduo. Assim como a criação de ordens sociais e institucionais, que são responsáveis pelos aspectos éticos e sociais da religião.

Todos estes aspectos apontam para uma complexidade no estudo do fenômeno religioso. Neste intuito, é necessário um núcleo operacional e uma abordagem específica para a melhor apreensão deste fenômeno.

O sagrado se apresenta como este núcleo operacional, pois representa o objeto de estudo como cerne da hierofania ${ }^{8}$ e a própria relação do homem religioso com o motivo de sua fé. O sagrado é o âmago do fenômeno religioso. Mesmo considerando os diversos matizes culturais da experiência religiosa, o sagrado se apresenta como base fundamental do fenômeno religioso. Neste contexto, as religiões se apresentam como modalidades do sagrado em várias temporalidades e espacialidades marcadas por rupturas.

Nesta abordagem, o pressuposto é de que a religião também é uma forma de conhecimento. Ela representa verdades relativas ao contexto histórico e geográfico, a despeito das instituições religiosas tradicionais a considerarem absolutas.

A partir da premissa de que a religião é uma forma de conhecimento relativo, é possível entendê-la como dinâmica e diversificada. Como tal, a consolidação do Ensino Religioso como disciplina escolar perpassa pelo redimensionamento temático.

Cassirer $^{9}$ admite que, muito embora a observação empírica coloque em questão a unicidade do pensamento religioso, são recorrentes ca-

8 O uso do termo hierofania, na perspectiva de ELIADE, refere-se à manifestação do sagrado que enseja uma experiência religiosa primária através da revelação de uma realidade de caráter absoluto. A manifestação do sagrado funda ontologicamente o mundo. ELIADE, M. O sagrado e o profano: a essência das religiões. São Paulo: Martins Fontes, 1995.

9 CASSIRER, E. A filosofia das formas simbólicas II - o pensamento mítico. São Paulo: Martins Fontes, 2004. 
racterísticas comuns aos diversos sistemas religiosos. O princípio de articulação das atividades religiosas é o mesmo. Esta articulação, por conseguinte, é funcional. Inferimos a idéia de um poder regulador que fornece coerência e estrutura ao pensamento religioso.

No pensamento de Cassirer $^{10}$, a natureza humana é considerada sob o aspecto funcional. Este pressuposto de definição de homem coloca de lado a premissa da essência metafísica e o instinto inato. Como teoria do homem, o autor propõe que as atividades humanas são o que define o devir da humanidade. Deste modo, linguagem, mito e religião são essenciais a este propósito.

A partir do argumento do autor, cada vez mais o homem afasta-se do universo dos fatos e aproxima-se do universo simbólico. Este homem como ser simbólico passa a reconhecer o mundo pelos seus significados. Desta forma, podemos identificar quatro meios de articulação do processo de significação e ressignificação do mundo: a linguagem, as artes, os mitos e a religião.

Deste modo, somos levados a procurar uma solução no conhecimento das estruturas das atividades humanas em seu todo. Linguagem, artes, mito e religião são componentes funcionais que permitem entender esta todalidade.

\section{Estruturas do pensamento religioso}

Tomamos em destaque as estruturas do pensamento religioso e mítico como formas de apreensão da realidade. No sentido funcional, a religião supera o caráter de objeto de análise e passa a ser considerada como forma de conhecimento. A partir desta premissa, existe uma visão mítica e religiosa do mundo ao qual o homem religioso, se projeta. Para comprendermos melhor o fenômeno religioso, podemos partir da desconstrução do pensamento mítico-religioso e assim inferirmos os sentidos das formas religiosas no tempo-espaço. A pista apontada por Cassirer é

10 CASSIRER, E. Ensaio sobre o homem - introdução a uma filosofia da cultura humana. São Paulo: Martins Fontes, 1997. 
que o tempo e o espaço para a visão mítico-religiosa não são homogêneos. No que tange ao tempo, não há uniformidade. Por mais que se universlize o seu conceito, há uma peculiaridade diferencial de como ele é dado. O tempo é qualificado nos contextos culturais e históricos e no modo como as religiões se desenvolveram. Esta percepção qualificada resulta na idéia de que o tempo sagrado e o espaço sagrado sejam inpregnados de rupturas qualitativas, de acordo com as ênfases da dialética sagrado e profano. Deste modo, o tempo não é apenas a seqüência dos acontecimentos, mas o sentido especial dado e a indentificação das singularidades de cada período.

Na lembrança de Halbwachs, o objetivo da religião é preservar intocável a lembrança de um momento ontológico considerado original no curso da história, sem que subseqüentes memórias comprometam o ponto inicial. ${ }^{11}$ Deste modo, podemos esperar a concepção da verdade absoluta, sendo que o rito assume cada vez mais modos de preservação do momento primordial. Estas formas simbólicas apresentam um caráter de memória religiosa, presentes no discurso religioso de caráter apologético em relação a outros grupos religiosos. Quanto mais a memória religiosa se distancia dos eventos fundadores, tende a rejeitar outras memórias, pois se realiza em uma dialética entre a memória ancestral e os eventos hodiernos que coloca em questão a ortodoxia religiosa.

A pós-modernidade apresenta temporalidades superpostas que, em última instância, evidenciam o pluralismo religioso como forma impactante da religião e de conhecimento também realizado no âmbito da escola. A experiência do tempo, sob a ótica da ortodoxia religiosa, encontra a oposição da velocidade e fracionamento dos discursos no mundo pós-moderno.

Nossa opção é a superação do tempo absoluto e da verdade absoluta no que se refere à religião como conhecimento. As temporalidades religiosas diferem das temporalidades seculares. A constituição da rede de relações que identificam um período na História religiosa possui operações culturais específicas, iniciadas num passado que deste modo trazemos à tona no presente. A lembrança de Le Goff: “a oposição passado/presente é essencial na aquisição da consciência do tempo.” ${ }^{12}$ Esta oposição é edificada

11 HALBWACHS, M. On colective memory. Chicago: The University of Chicago Press, 1992.

12 LE GOFF, J. História e memória. Campinas: Unicamp, 1996. 
e está submetida à temporalidade do sujeito que a constrói. As temporalidades religiosas são temporalidades das hierofanias e a gestão do espaço sagrado. A partir destes pontos configura-se uma rede de relações que tecem a trama da história religiosa.

O sagrado, considera Rehfeld, é como aquilo que retorna no tempo. ${ }^{13}$ Uma reminiscência duradoura que se distingue do não-sagrado, pois atribui significados à vida do homem diante do cotidiano. O tempo sagrado refere-se à lembrança de uma série de fatos que, periodicamente, são evocados nos ritos e festas sagradas. As características do tempo sagrado são a permanência e o reavivamento sistemático de um passado específico, em uma temporalidade primordial.

São tempos construídos pelo discurso, que se apresentam na realidade cotidiana, provocando as rupturas qualitativas onde discernimos o sagrado. É um tempo ligado ao contexto das ações simbólicas que nos fazem articular as outras dimensões de imanência e transcendência. São também metáforas estruturadas que reúnem as pessoas nas práticas rituais religiosas.

Segundo Cassirer “(...) para a concepção mítico-religiosa não se trata de uma síntese puramente lógica, da reunião do ‘agora’ com o ‘antes’ e ‘depois’ na unidade ‘trancendental da percepção’, mas aqui tudo depende de qual direção da consciência temporal adquire preponderância sobre todas as outras." Para o autor existem diferentes "sentimentos de tempo"14 no plano da História da Religião e é justamente nesta alternância na percepção e significação do tempo que reside as diferenças no caráter de cada religião.

Do mesmo modo, o espaço é singular na intuição mítico-religiosa. Ele ocupa uma posição intermediária entre o espaço concreto material e o espaço abstrato, geométrico, do conhecimento puro. O espaço concreto é o espaço sensível que não é coincidente com a apreensão do espaço abstrato. O espaço material possui múltiplas determinações da percepção do sensível, que necessitam ser superadas para podermos atingir o espaço do conhecimento puro. Deste modo, o espaço abstrato tende à homogeinidade, suas inferências pessupõem noções de situação, porém desprovidas de con- 
teúdo autônomo. No pensamento cassireniano, o ser do espaço abstrato é puramente funcional e não substancial. Tendo em vista que não há conteúdo em sua idealidade, também não é possível o atributo da diversidade; portanto, é homogêneo. O espaço homogêneo é um espaço concebido, realizado em sua lógica funcional. Todavia, no espaço sensível estes atributos não são possíveis, pois cada lugar tem um significado singular, tem um valor próprio. Sendo assim, o espaço sagrado está muito mais próximo de um espaço da percepção do que os espaços concebidos pelo intelecto.

O espaço sagrado é um espaço produto da consciência religiosa concreta. Neste contexto, não é possível a separação entre posição e conteúdo, pois o último parte de uma consciência do vivido plenamente sensível. Sendo assim, em seu caráter, o espaço concreto percebido e o espaço sagrado são avessos à descrição universal e conceitual, mas são vividos como tal. A cada posição no espaço sagrado convergem valores afetivos específicos atribuídos pelo homem religioso, sendo este um espaço da intuição que distingue o sagrado do profano.

O fenômeno religioso é uma realidade que se apresenta no espaçotempo do cotidiano que nos permite estudá-lo à escala das Ciências Humanas. O sagrado como conceito-chave torna este estudo operacional, porque perpassa as várias instâncias do fenômeno religioso.

\section{Considerações finais}

O Ensino Religioso nas escolas e sua crise epistemológica é ainda inconcluso. Muito embora os ditames da pós-modernidade e as renovadas pressões do pluralismo religioso no Brasil criem um caldo cultural sem precedentes na história da disciplina, seu destino ainda é incerto. Tanto quanto incertas são as mudanças estruturais da instituição Escola no Brasil. Não podemos separar estas realidades, contexto e pensamento sobre o mesmo mundo.

O que diagnosticamos em uma primeira aproximação é que o Ensino Religioso precisa imprimir uma nova semântica no espaço escolar, desprender-se do seu passado confessional e recente interconfessional, para poder alcançar seu status de disciplina autônoma. Renovar seu comprome- 
timento com o processo do conhecimento no meio científico e, por que não dizer, no próprio seio das instituições religiosas. Aparece, então, a oportunidade de repensarmos a religião como forma de conhecimento necessário no devir da sociedade. Além de uma razão de fé assumir uma razão de entendimento do mundo.

Pensar o Ensino Religioso como disciplina autônoma requer rever nossos paradigmas, muitas vezes diferentes daqueles cristalizados nos discursos dos líderes religiosos e dos especialistas da religião. Desde modo, os interesses das estruturas de poder religiosas já postas na instrumentalização da disciplina, mediadas por vezes pela política secular, são colocados em questão. Repensar o objeto desta renascida disciplina é mais que um desafio técnico-científico: é a busca quase arquetípica da essência da convivência e interação do homem com o sagrado.

A objetivação do sagrado como foco do fenômeno religioso, consolidando um redimensionamento do objeto do Ensino Religioso, tem fortalezas e fragilidades devido à polissemia do conceito. Pois o sagrado é o qualitativo da hierofania no espaço-tempo, é o objeto de culto, é o culto per si. São as relações sociais por ele motivadas e é inclusive um prisma por meio do qual interpretamos e avaliamos o mundo. Como categoria ele tem conteúdo, forma, função e estrutura, que nos permite entendê-lo sob a razão conceitual e compreendê-lo nas nuanças do seu sentido subjetivo. Todavia, este espectro de possibilidades revela também as dificuldades de sistematizá-lo no plano pedagógico. Mas, este é o desafio do pensar a disciplina no labor do processo ensino-aprendisagem, não para fornecemos as respostas prontas, mas para rever nossas posições no plano do discurso acadêmico e religioso. 